UDC 616.248

\title{
Nitrosative events in atopic asthma pathogenesis
}

\author{
O. O. Parilova, T. T. Volodina, S. G. Shandrenko \\ Palladin Institute of Biochemistry, NAS of Ukraine \\ 9, Leontovycha Str., Kyiv, Ukraine, 01030 \\ elenparil@gmail.com
}

\begin{abstract}
The correlation between high exhaled nitric oxide levels and eosinophilic-mediated airway inflammation in patients with atopic asthma has been well documented. This generates prerequisites that a regulatory feedback mechanism exists between them. Therefore, the paper briefly describes evidence implementing biosynthesis, enzyme structural features, expression regulation of its isoforms and effects of nitric oxide, which have helped elucidate molecular mechanisms by which nitric oxide selectively promotes asthma exacerbation. In previous study we have demonstrated that airway infiltrate of immune cells contributes to NO synthesis in the respiratory tract during allergic inflammation under guinea pig model of acute asthma with multiple challenges. On the basis of these findings the authors posits that nitric oxide represents an additional signal of the induction of Th2 subset response and be considerably involved in the complex network of immune regulation distinctive for atopic asthma phenotype.
\end{abstract}

Ke yw or d s: nitric oxide, atopic asthma, nitric oxide synthases, allergic airway inflammation, eosinophilia.

\section{Introduction}

Asthma is a chronic inflammation of the airways that involves airflow obstruction and increased airway responsiveness to a variety of stimuli, which leads to the symptoms of recurrent coughing and dyspnea [1]. Albeit the understanding of disease pathogenesis has progressed enormously in the last several decades [1-3], asthma is still a major public health problem, affecting 300 million people worldwide and rapidly increasing in all age groups $[4,5]$. Clinically, several distinct phenotypes are recognized, but the therapy and research have been basically focused on allergic (atopic) asthma [1-3].

Currently, the routine asthma treatment relies on suppressing the inflammation (glucocorticoids, leukotriene inhibitors as additional medication) as well as removal of bronchoconstriction ( $\beta$ agonists, anticholinergics) $[6,7]$. The symptom-based guidance of treatment could predispose to an increased num- ber of exacerbations. Thus, asthmatics might benefit from the inflammatory marker-addressed therapy [1, 8]. Although many physiologic processes have been implicated in asthma pathogenesis, the range of evidence supports the key roles of endogenous nitric oxide (NO) and NO-derived reactive nitrogen species (RNS) in modulating either a normal airway function $[8,9]$ or inflammation in asthma $[10,11]$. Therefore, NO has received a tremendous amount of attention in the medical community as a selective pulmonary disorder marker $[8,12,13]$.

$\mathrm{NO}$ is an ubiquitous messenger that regulates various biological functions - either at low concentrations as a signal molecule in many physiological processes, or at high concentrations as cytotoxic and cytostatic defensive mechanisms against tumors and pathogens $[9,11]$. Also it is thought to be a marker of lung inflammation. NO is detected in exhaled breath $[8,12,13]$. Fractional exhaled NO (FeNO) levels were shown to correlate with sputum eosinophil

(C) 2015 O. O. Parilova et al.; Published by the Institute of Molecular Biology and Genetics, NAS of Ukraine on behalf of Biopolymers and Cell. This is an Open Access article distributed under the terms of the Creative Commons Attribution License (http://creativecommons.org/licenses/by/4.0/), which permits unrestricted reuse, distribution, and reproduction in any medium, provided the original work is properly cited 
count, airway hyperresponsiveness, bronchodilator response, serum IgE levels, allergen skin prick testing, asthma symptoms, and lung function. This led to the general belief that atopy is associated with higher levels of exhaled NO (eNO) [11].

From this background, the current article deals with the consideration of the source of NO formation and its triggers in asthma pathogenesis. We aim to discuss the cases, when NO becomes a marker of allergic inflammation. Simultaneously, we present our data that revealed the contribution of immune cells settling down the airways to the respiratory NO generation.

\section{Biosynthesis and enzyme structure basis}

The role of NO in the human body is under the scope of intensive research. NO is generated by oxidation of L-arginine; this reaction is typically catalyzed by the nitric oxide synthases (NOS) [9] in the presence of several co-factors: flavones (FAD, FMN), tetrahydrobiopterin (BH4) and NADPH [14]. NOS are stereospecific and active as homodimers [14]. The enzyme exists in three isoforms: neuronal NOS (nNOS/ NOS1), inducible NOS (iNOS/NOS2) and endothelial NOS (eNOS/NOS3) [15-18].

nNOS and eNOS are constitutively expressed isoforms (cNOS) in cells as the preformed proteins that are activated in response to the cell-specific stimuli through the elevation of intracellular $\mathrm{Ca}^{2+}$ concentrations and the binding of calmodulin. iNOS form is generally associated with the immune system and produces NO for prolonged periods of time in a calcium-independent manner [9-11, 14-22]. iNOS is activated by bacterial lipopolysaccharides and proinflammatory cytokines such as inteleukin-1, TNF- $\alpha$, IFN- $\gamma$ [15]. However, IFN- $\gamma$ is the most potent and prevailing inducer of iNOS in vivo [23]. As T-lymphocytes and NK-cells are the main source of IFN- $\gamma$ production, the iNOS induction is mediated by them. The endothelial cell derived factor, endothelin-1 (ET-1), has been shown to promote iNOS expression [24, 25]. Ultimately, iNOS incorporates a calmodulin binding site to which the calmodulin is tightly bound independently of a calcium signal - this is thought to be responsible for the continuous activity of the enzyme [15-17]. Up to 1000 times higher levels of NO can be generated by iNOS compared to cNOS [11, 19].

The NOS enzyme functions as a dimer consisting of two identical monomers, which can be functionally and structurally divided into two major domains: a $\mathrm{C}$-terminal reductase domain and an $\mathrm{N}$-terminal oxygenase (catalytic) domain. All NOS isoforms are members of the cytochrome P450 enzyme group owing to the presence of a haem complex [20]. Thus the mammalian NOS share similar domain architecture, with an N-terminal catalytic domain containing a haem active site, a nearby cofactor site for $\mathrm{BH} 4$ and a $\mathrm{C}$-terminal reductase domain consisting of FMN, FAD and NADPH binding sites. We visualized catalytic domain of human NOS enzymes in three-dimensional form using PDB files via Cn3D viewer from MMDB (Fig. 1). The macromolecular 3D structures display the evidence, that eNOS and iNOS isoforms are very similar in the overall molecular shape, relative orientation of cofactors and stereochemistry within the catalytic centre. As the catalytic sites of iNOS and eNOS are so similar it is not obvious from a structural starting point how the selective inhibitors may be designed [26].

\section{Localization of nitric oxide synthase iso- forms in respiratory tract and its biological role}

In the respiratory tract all isoforms have been identified $[20,21]$. cNOS-derived NO along with other $\mathrm{NO}$ adduct molecules are involved in maintaining normal metabolic functions, such as airway and pulmonary vascular tone, intracellular signaling, immunity (platelet aggregation, leukocyte adhesion) and neurotransmission [7, 22]. By contrast to this, iNOSderived NO seems to play a pro-inflammatory primary role in the cytokine dependent processes [19]. Albeit, agonists such as sheer stress, bradykinin, acetylcholine and histamine still may activate cNOS, resulting in the release of NO within seconds [20].

eNOS is constitutively expressed in both the endothelial cells of the bronchial and pulmonary circu- 
lation and the alveolar endothelial cells, and airway epithelial cells throughout the respiratory tract [27]. The traces of NO from eNOS activity have been isolated in the airway epithelium and found to participate in ciliary movement and mucus ejection [28, 29]. Although eNOS is present in airway epithelium, iNOS is considered to be a predominant form in it [19]. The recent evidence has demonstrated a link between certain eNOS gene polymorphisms and increased serum IgE levels in patients with allergic asthma [30]. Functionally, nNOS mediates neuronal bronchodilation in the skeletal muscles and cholinergic airway nerves [27]. When allergic asthma was being launched, the increased arginase activity attenuates the nNOS-catalyzed synthesis of NO and induces neural bronchoconstriction [31]. In this way cNOS isoforms reveal an indirect involvement in asthma pathophysiology.

In general, iNOS regulates approximately 200 genes that are relevant to inflammation, infection or apoptosis [21]. In the airways iNOS is expressed by epithelial and endothelial cells $[23,32]$, smooth muscle cells [18, 32,33], lung fibroblasts [34]. In contrast to other cell types that do not express NOS2 unless induced by cytokines, the NOS 2 mRNA expression and NOS2 protein were detected in epithelial cells of normal, noninflamed upper and lower airways and in pulmonary myocytes of large hilar veins by a variety of techniques, including Northern blotting, in situ hybridization, Western blotting, and immunohistochemistry [23, 35]. Additionally, iNOS-derived NO is produced by the genuine immune-system cells including monocytes and macrophages [16, 17, 36], eosinophils [37, 38], neutrophils [39, 40], dendritic cells [41]. The reports about the NOS expression in the mast cell population appear to be ambiguous. The data presented in numerous papers clearly indicate distinct differences in diversity and localization of NOS in a variety of mast cell populations expressed in human and rodents [42-44]. Notably, the iNOS expression and NO generation are up-regulated by the antigen stimulation FceRI engagement in the different subsets of mast cells [44]. Additionally, the NO production prevents mitochondrial integrity collapse, thereby protecting mast cells against antigen-induced apoptosis [45]. Previously several reports have confirmed that the rat mast cells produce iNOS mRNA and the protein upon treatment [46-48]. However subsequent studies have demonstrated that some types of human mast cell were positive for eNOS but showed variable expression of $\mathrm{nNOS}$ and no detectable iNOS $[42,43]$. Together these findings suggest the important differences between the rat and human mast cells in the NO production and NO-mediated regulation of mast cell function [42]. NK cells express constitutive eNOS mRNA and protein, however the levels of iNOS are not detectable. The endogenous NO production is involved in protection of NK cells from activation of apoptosis induced by CD16 cross-linking, thereby maintaining NK activity [49]. This is the further evidence that, unlike NO produced by iNOS, cNOS-derived NO is critical for normal physiology.

Farther, the biological effect of NO ultimately depends on its concentration and interaction with other bioreactive molecules and proteins [50]. NO can be converted to $\mathrm{NO} 2, \mathrm{NO} 2-, \mathrm{NO} 3-$ and other reactive nitrogen intermediates (RNI), among which the most important are S-nitrosothiols (S-NO), peroxynitrite (ONOO-) and nitrosyl-metal complexes, which are directly implicated in the RNI-mediated free radical reactions (S-nitrosylation of cysteines, nitration of tyrosines, and nitrosylation of prosthetic groups, respectively) [51]. In summary, the excessive NOadduct molecules namely $\mathrm{ONOO}-$, nitrogen dioxide (NO2), dinitrogen trioxide (N2O3), and higher oxides of nitrogen can provoke detrimental post-translational modifications $[13,50,52]$.

\section{Nitric oxide formation as a marker of Th2-mediated infllammation}

There is rising evidence for an important immunoregulatory role of $\mathrm{NO}$ in the development of the adaptive immune responses associated with autoimmune and allergic diseases. Increased levels of exhaled NO [53-56] along with an up-regulation of iNOS in asthmatic airways [57] confirm that this radical should be involved in asthma. It has been 
demonstrated, that, in humans, a higher than normal NO concentration in exhaled breath is closely associated with the enlarged transcriptional activation of NOS2 gene [58].

Nevertheless, the previous studies, using murine and guinea pig models of asthma and iNOS inhibitor treatment or iNOS-deficient animals, have generated controversial results. In two different studies, iNOS deficiency [59] or iNOS inhibitor treatment [60] had no effect on the lung inflammation, whereas in other study the airway inflammation was inhibited in the iNOS deficient mice [61]. Such a discrepancy was attributed to significant differences in the immunization and challenge protocols [59].

Further investigations have shown that inhibited iNOS activity correlates with a decrease of nitrotyrosine and, more importantly, ameliorates FEV1 and airway responsiveness to histamine [14]. However, the different subgroups analysis of atopic individuals now suggests that it is the inflammation in atopic individuals with clinical manifestations of airway disease, rather than atopy itself, that accounts for the increased production of NO by iNOS [62]. eNO was commonly regarded qua a marker of eosinophilic inflammation [63-65]. In addition, the 2011 American Thoracic Society (ATS) guideline for the use of FeNO in clinical practice characterized FeNO as an indicator of eosinophilic airway inflammation [12]. However, the recent studies have indicated that FeNO is more representative of a Th2-driven local inflammation, specifically of the bronchial mucosa, rather than general eosinophilic inflammation, as measured by blood or induced sputum [66]. The disconnect between FeNO and eosinophilic inflammation has been highlighted by two separate studies with monoclonal antibodies (mAb) against IL-5 and IL-13, which indicate that treatment with mepolizumab, an anti-IL-5 mAb, significantly reduces blood and sputum eosinophils without affecting FeNO levels [67] whereas treatment with lebrikizumab, an anti-IL-13 mAb, significantly reduces FeNO levels without reducing blood eosinophils [68]. Another research has shown that, in asthmatic children but not in controls, eNO levels and BAL fluid eosinophil percentages correlate well regardless of the methods used to measure eNO [69]. Thus, eNO levels interconnect better with bronchial eosinophils than with sputum eosinophils.

Based on the findings of the bronchoalveolar lavage fluid (BALF) studies and the lung tissue histological analysis, the mechanisms for late allergic responsiveness (LAR) are considered to be causally related to the infiltration of eosinophils and other inflammatory cells into the bronchial mucosa [70]. It has been suggested that NO play an important role in LAR $[10,71]$. In the airways of asthmatic patients [57] or in rodent lung after allergen challenge [61, 72], iNOS expression and/or enzymatic activity are increased.

To give insight into the role of nitrosative stress established by immune cells infiltrating the airways we examined the NO formation in BAL cells under the guinea pig model of acute ovalbumin (OVA)induced asthma with repeated challenges following 32 weeks after sensitization [73]. This model mimics those seen in humans exposed to an allergen a long period after acquired hypersensitivity. A suggested protocol reflects the allergen-driven pathway of asthma reproducing several characteristic features, such as airways infiltration by inflammatory cells, early allergic responsiveness (EAR) and LAR, AHR. Flow cytometry analysis using DAF-2DA dye showed, that multiple allergen challenge exposures of sensitized guinea pigs were associated with an excessive level of the intracellular NO generation in BAL cells (Figure 2). Hence, OVA aerosol provocations of guinea pigs with sensitization resulted in a substantial growth of BAL cells containing NO in comparison with sensitized group (33.50[27.80 $45.80] \%$ versus $6.30[2.20-7.82] \% ; p=0.0001)$. Our results are in line with the data confirming that allergic inflammation is accompanied by NO. Moreover, there is apparent evidence that iNOS inhibition, during the challenge period, markedly reduced the development of the inflammatory process in the OVA-induced murine model after allergen challenge through down-regulation of chemokine expression [74]. 

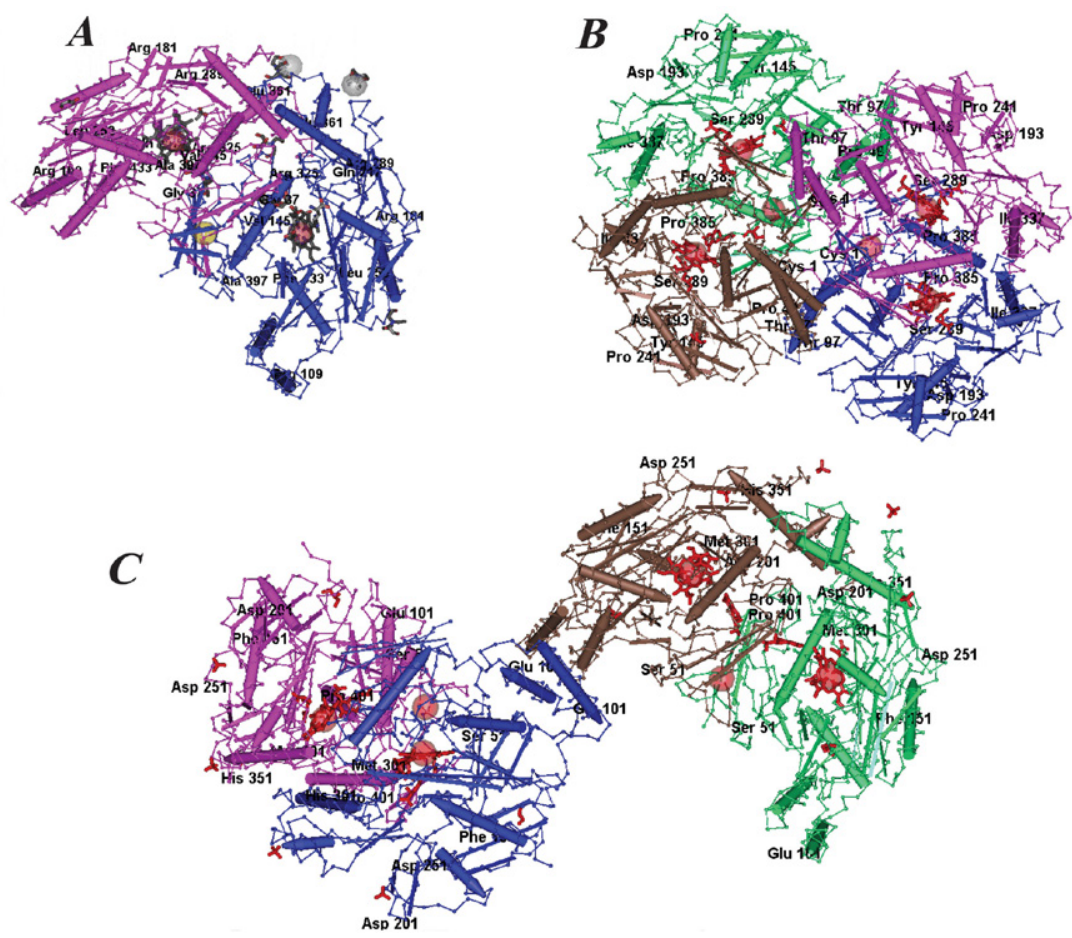

Fig. 1. The structures of oxygenase domain of human NOS isoforms.

$A$ - dimeric unit of eNOS haem domain with L-arginine bound (PBD ID:4D1O). $B$ - tetrameric unit of nNOS haem domain with L-arginine bound (PBD ID: 4D1N). $C$ - tetrameric unit of iNOS with Zn-bound and L-arginine complex (PBD ID: 1NSI). The enzyme structures show a ball and stick backbone in a trace shape, no side chains to alignment protein views, and solid objects - condensed lines and massive cylinders with arrows - to represent strands and helices. The arrows on helix cylinders point in the N-to-C direction. The extent of each monomer element in macromolecule is designated by color (blue, violet, green and brown). Haem, BH4 and arginine, glycerol are shown in a tube representation. The association into a dimer involves a large interface, which includes the binding site for $\mathrm{BH} 4$ and helps to structure the active-site pocket containing the haem and the L-arginine binding site
Taking into account that BAL explores large areas of the alveolar compartment providing cellular constituents from the lower respiratory tract, we identified the alterations in cellular composition of
BAL as indicated in FACS density graphs (Fig. 3). OVA provocations in sensitized animals were shown to cause a strong inflammation in lungs. This led to the redistribution of immune subpopula-
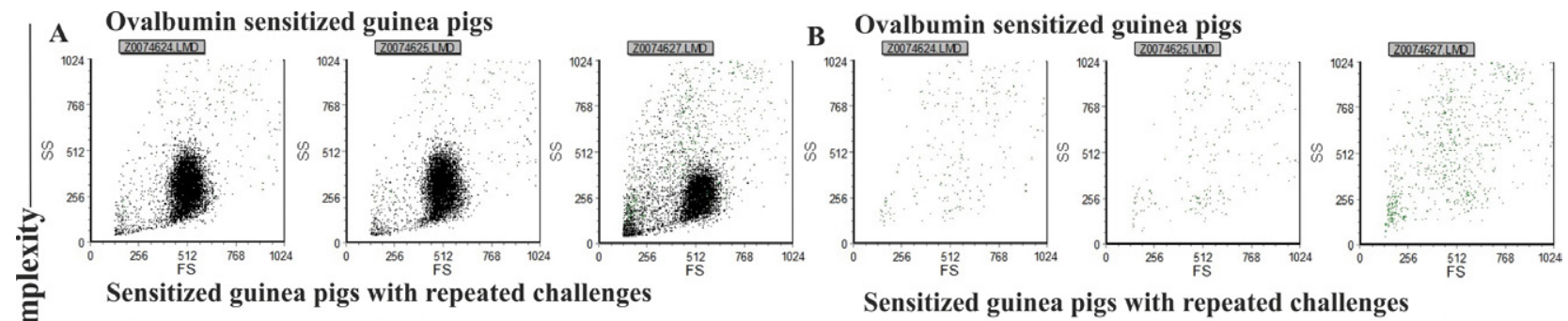

Sensitized guinea pigs with repeated challenges
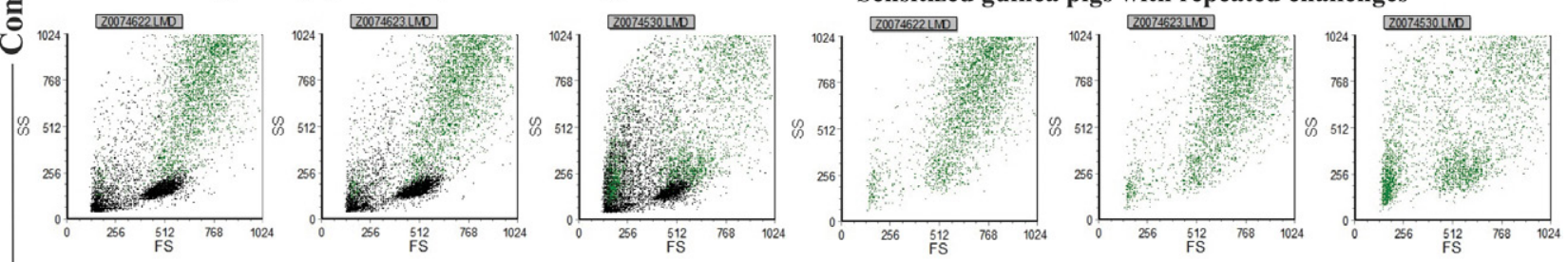

Cell size

Fig. 2. NO content in BAL cells 18-20 h after induction of allergic lung inflammation: morphological flow cytometric parameters of cell types concerning size (FS) and granularity (SS). Panel A: BAL cells derived from sensitized guinea pigs with allergen challenges (II coumn) display augment of NO generation compared to sensitized animals (I column). Panel B: fractions of BAL cells incorporating NO from two compared groups (I and II columns) are also demonstrated in the individual dot plots. Green-colored cells include NO molecules (adopted from [73] and supplemented in this paper) 


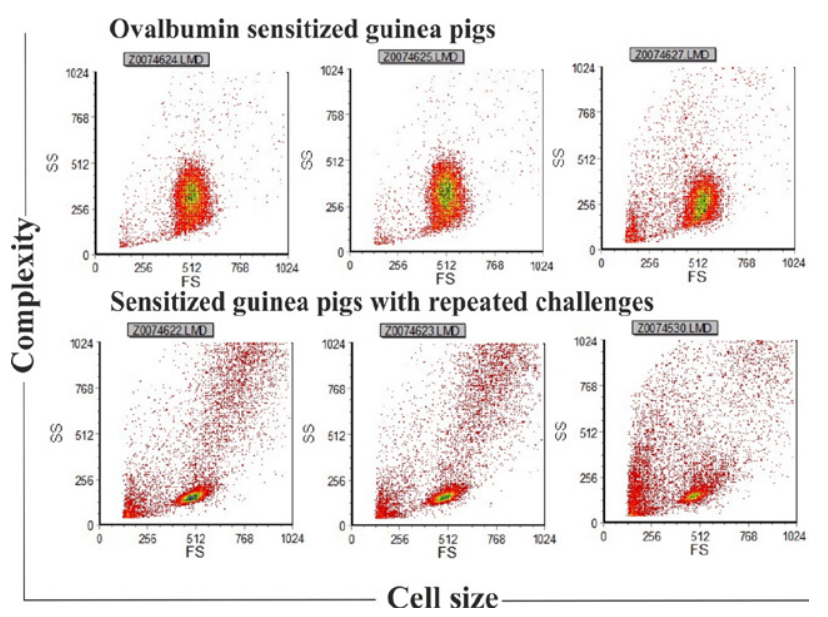

Fig. 3. Distinction of BAL cellular compostion of sensitized guinea pigs (I column) compared to sensitized animals, that received allergen challenges (II column). Subpopulation content and ratio in BAL suspensions based on the morphological flow cytometric parameters side scatter (SS) versus forward scatter (FS) are illustrated in density plots

tions in the general pool of cells infiltrating respiratory tract.

In addition to quantitative assessment of $\mathrm{NO}$ formation, the allocation of intracellular NO content in BAL suspension was analyzed depending on the size and granularity (Fig. 4, Fig. 5) [73].

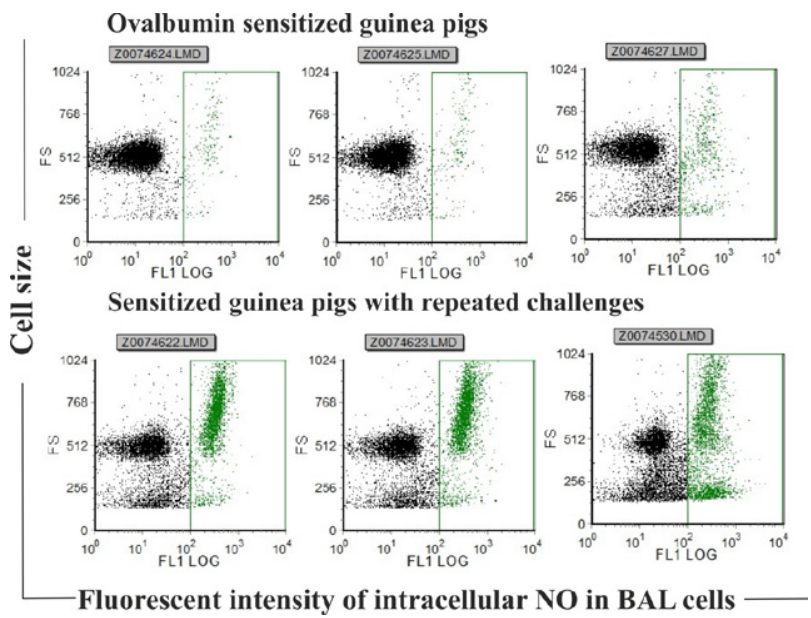

Fig. 4. NO formation as a function of cellular size in BALF subpopulations derived from OVA sensitized guinea pigs (I column) and OVA sensitized animals treated with OVA aerosol exposures (II column). DAF-2DA stained cells are colored in green ( $\mathrm{ad}$ opted from [73] and supplemented here)
In view of these findings we infer that in asthma, due to increased iNOS protein expression and activity, the excessive NO generation is activated in lung tissue cells (mainly airway epithelial cells), but also in multi-cellular airway infiltrate recruited to trigger organ during allergic inflammation. High BAL levels of NO may reflect circulating nitrosative stress in respiratory tract, when exacerbation in asthma is present. Indeed inhibition of iNOS-derived NO attenuates antigen-induced airway constriction, inflammatory, and reduces collagen and elastic fiber deposition in a guinea pig model of allergic asthma [37].

\section{Immunoregulatory cross-talk of nitric oxide in asthma pathogenesis}

The network of molecules involved in the allergic inflammatory processes becomes more complex since NO derivatives have been demonstrated to play a role in these reactions. The allergic disorder pathogenesis is modulated by NO at the level of immune system $[20,32]$. In turn, iNOS transcription is regulated by a number of pathways, including the JNK, JAK-STAT, and p38 MAPK pathways, which are largely activated through the cytokine induction

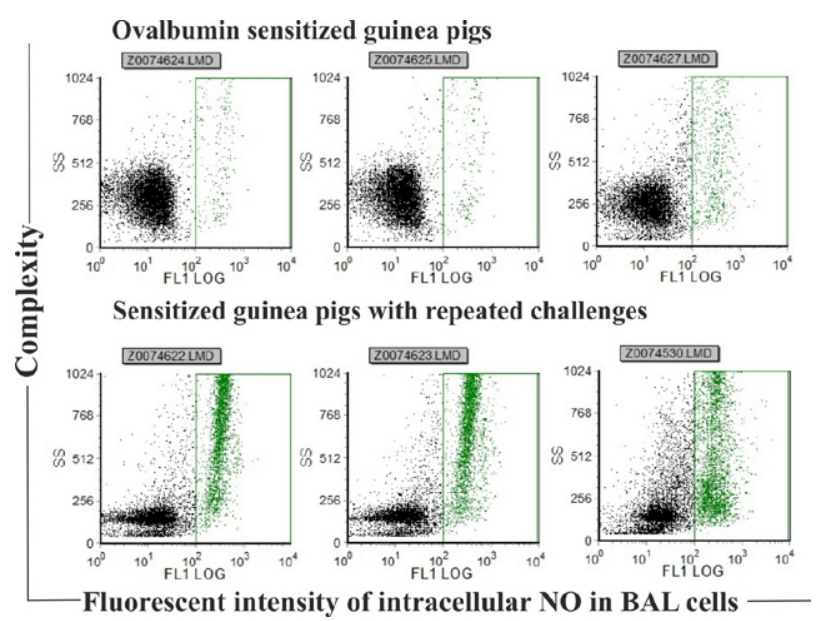

Fig. 5. NO generation in accordance with the complexity of BALF cell subpopulations of OVA sensitized guinea pigs (I column) and of OVA sensitized animals treated with OVA aerosol exposures (II column). DAF-2DA stained cells are colored in green (adopted from [73] and supplemented here) 
[75]. In allergic asthma the immune response to inhaled antigens results from the activation of mast cells and antigen-specific Th2 cells, followed by the production of cytokines, including interleukin IL-4, IL-5 and IL-13 [3]. Further, IL-4 and IL-13 cause lung epithelial expression of iNOS to be upregulated via STAT-6, a process which is corticosteroid sensitive [76]. Moreover, the group of researchers provided evidence, that IL-13 robustly induces the expression of an active dimeric iNOS enzyme in primary HAEC (human airway epithelial cells) maintained in air-liquid interface culture, consistent with its expression in relation to Th2 inflammation [77]. Therefore, eNO is a direct signal of the Th2mediated, pro-inflammatory cytokine mechanisms of central importance in the pathophysiology of allergic airway inflammation. At present, there is open debate about whether NO exacerbates or reduces autoimmune and allergic chronic inflammation.

The detrimental impact of NO is implemented due to its ability to launch a hyperinflammatory response, leading to tissue damage. Two mechanisms are primarily responsible for inducing NO-mediated damage: action of NO-induced inflammatory mediators and apoptosis of NO-targeted cells. NO modulates the production and function of cytokines released by immune cells, chemokines, and growth factors [78]. NO-mediated apoptosis represents one of the key factors contributing to enhanced inflammation and tissue damage during noninfectious respiratory diseases, such as asthma [79]. The recent study has revealed that NO induces eosinophil apoptosis in a mechanism mediated via ROS, JNK, and later mitochondrial permeability transition [80].

iNOS-derived NO plays an immunomodulatory role, as it may shift the Th1/Th2 balance in favor of $\mathrm{Th} 2$, thus promoting IgE-mediated allergy $[75,81]$. Th1 cells secrete IFN- $\gamma$, TNF- $\alpha$, and IL- 2 and promote cellular immune responses against intracellular antigens, whereas Th2 cells secrete IL-4, IL-5, IL10, and IL-13, induce IgG1- and IgE-mediated humoral responses, and are important for the elimination of large extracellular parasites such as helminthes and nematodes [82]. The molecular mechanisms of Th1 versus Th2 regulation rely on the counterbalance between expression of the IL-12 receptor $\beta_{2}$ chain (IL-12R $\left.\beta_{2}\right)^{3}$ on Th1 cells and GATA-3 transcription in Th2 cells. IL-4 induced GATA-3 allows the stable commitment to the Th2 phenotype through promotion of Th2 cytokine production, such as IL-4, IL-5, IL-10 and IL-13 [83, 84]. IL-10 produced by Th 2 cells further suppresses the Th1 development by inhibiting the secretion of IFN- $\gamma$ and IL-12 and may also directly inhibit the induction of iNOS [81]. Moreover, NO markedly inhibits the induction of IL-2 promoter, which could account for most of the reduction in IL-2 production, and increases the production of IL-4 by effector T cells [85]. To conclude, NO can inhibit Th1 lymphokines but has no direct impact on the Th2 lymphokines production [78, 81]. As the continuous expression of iNOS in the normal epithelium is maintained mainly by IFN $-\gamma[19,21$, $23]$, the present observations indicated that NO selectively inhibits the expansion of Th1 cells by a negative feedback mechanism. In contrast, low concentrations of NO stimulate T cells to express IL12R and promote Th1 differentiation [86].

The counter-evidence of the absence of a direct effect of NO on Th2 cells was found since the NO donors inhibit the proliferation of Th1 and Th2 populations. The NO donors SIN-1 (3-morpholino-sydnonimine) and SNAP (S-nitroso-N-acetyl-DLpenicillamine) suppress the proliferation of antiCD3 or mitogen activated human peripheral Th1 and $\mathrm{Th} 2$ cell clones, and prevent the release of IFN $-\gamma$, IL-2, IL-4, IL-5 and IL-10 [87]. Additionally it has also been reported that NO inclusion to human bronchial epithelial cells reversibly inhibits the proliferation of activated Th1 and Th2 CD4+ T cells in atopic asthma [88].

IgE-dependent synthesis of NO by various cell populations bearing low-affinity IgE receptors (FceRII; CD23) implicates in local allergic and inflammatory reactions, including macrophages, eosinophils and keratinocytes [89]. NO is also an important agent in eosinophil migration and infiltration. Several reports demonstrated that the acute treatment with the non-selective inhibitors of $\mathrm{NO}$ 
reduced allergen-induced eosinophilia, showing that $\mathrm{NO}$ is involved in the inflammatory cell recruitment $[44,90,91]$. Furthermore, it has been found that the 1-NAME (N $\omega$-nitro-l-arginine methyl ester) treatment decreases the number of eosinophils positive for both nNOS and iNOS, whereas the treatment with $1400 \mathrm{~W}$, a highly selective iNOS inhibitor, decreases only the iNOS-positive eosinophils, reducing the eosinophil density in alveolar septa of allergen-sensitized animals [92]. In addition to these findings, NO is crucial to the numerous mast cell functions, including degranulation, adhesion, and protease release, as well as the production and secretion of chemokines and cytokines [42]. NO also controls the processes in immune system through regulation of the chemokine expression. Among the asthma pathophysiology processes, involving NO, are modulation of the co-stimulatory and adhesion molecules, such as VCAM-1 (vascular cell adhesion molecule-1), ICAM-1 (intercellular adhesion molecule-1), CD62E (E-selectin) and CD62P (P-selectin), synthesis and deposition of the extracellular material components via TGF- $\beta$ [93].

The anti-inflammatory effects of NO may be mediated by several mechanisms including the inhibition of gene expression and the secretion of proinflammatory cytokines [94, 95], reduction of the proinflammatory effects of cytokines such as IL-8 through the covalent modification by nitration of tyrosine [96], or by protection against the programmed cell death through inactivation of the proteolytic enzymes responsible for apoptosis [97, 98]. Thus, the endogenous NO synthesis in asthma, may be an important early physiological defense mechanism against the injury and inflammation. Nevertheless, persistently elevated levels of the NO formation can deepen the tissue injury over time.

\section{Conclusions}

The presented evidence posits the nitrosative stress as a relevant pathogenic mechanism underlying atopic asthma. The diversity of NOS enzymes produces different profiles of NO activities as well as of its derivatives facilitating and broadening the func- tional versatility of nitrosative events. Many studies and clinical observations are bringing to light a multitude of different mechanisms through which NO operates in respiratory tract and mediates dysfunction in the disease. Mounting evidence of a link between the NO synthesis and the allergic inflammation raises the possibilities for therapeutic intervention. Two major challenges currently hinder the progress towards this aim; on one hand the multiplicity of asthma nature with a complex immunogenetic basis and a strong environmental contribution; on the other hand the likelihood of mimicking the full spectrum of responses to the allergen exposures and the tested pharmaceuticals by in vivo and in vitro models seems fragile. Hence, despite the significant advances in our understanding, the effective markeraddressed therapy strategies and reliable approaches for the precise diagnostics and monitoring are currently still limited.

\section{REFERENCES}

1. Busse WW, Lemanske RF Jr. Asthma. $N$ Engl $J$ Med. 2001;344(5):350-62.

2. Schröder $N W$, Maurer $M$. The role of innate immunity in asthma: leads and lessons from mouse models. Allergy. 2007;62(6):579-90.

3. Gaston B. The biochemistry of asthma. Biochim Biophys Acta. 2011;1810(11):1017-24.

4. Asher MI, Montefort S, Björkstén B, Lai CK, Strachan DP, Weiland SK, Williams H; ISAAC Phase Three Study Group. Worldwide time trends in the prevalence of symptoms of asthma, allergic rhinoconjunctivitis, and eczema in childhood: ISAAC Phases One and Three repeat multicountry cross-sectional surveys. Lancet. 2006;368(9537):733-43.

5. Illi S, von Mutius E, Lau S, Niggemann B, Grüber C, Wahn U; Multicentre Allergy Study (MAS) group. Perennial allergen sensitisation early in life and chronic asthma in children: a birth cohort study. Lancet. 2006;368(9537):763-70.

6. Ducharme FM. Inhaled corticosteroids versus leukotriene antagonists as first-line therapy for asthma: a systematic review of current evidence. Treat Respir Med. 2004;3(6):399405.

7. Colucci R, Fornai M, Tuccori M, Antonioli L, Pasqualetti G, Blandizzi C, Del Tacca M. Tolerability profiles of leukotriene receptor antagonists and long-acting beta2-adrenoceptor agonists in combination with inhaled corticosteroids for treatment of asthma: a review. $J$ Asthma. 2007;44(6):411-22. 
Nitrosative events in atopic asthma pathogenesis

8. Shorter JH, Nelson DD, McManus JB, Zahniser MS, Sama $S$, Milton DK. Clinical study of multiple breath biomarkers of asthma and COPD (NO, CO2, CO and N2O) by infrared laser spectroscopy. J Breath Res. 2011;5(3):037108.

9. Moncada $S$, Higgs $A$. The L-arginine-nitric oxide pathway. N Engl J Med. 1993;329(27):2002-12.

10. Ghosh S, Erzurum SC. Nitric oxide metabolism in asthma pathophysiology. Biochim Biophys Acta. 2011;1810(11):1008-16.

11. Ricciardolo FL, Sterk PJ, Gaston B, Folkerts G. Nitric oxide in health and disease of the respiratory system. Physiol Rev. 2004;84(3):731-65.

12. Dweik RA, Boggs PB, Erzurum SC, Irvin CG, Leigh $M W$, Lundberg JO, Olin AC, Plummer AL, Taylor DR; American Thoracic Society Committee on Interpretation of Exhaled Nitric Oxide Levels (FENO) for Clinical Applications. An official ATS clinical practice guideline: interpretation of exhaled nitric oxide levels (FENO) for clinical applications. Am J Respir Crit Care Med. 2011;184(5):602-15.

13. American Thoracic Society; European Respiratory Society. ATS/ERS recommendations for standardized procedures for the online and offline measurement of exhaled lower respiratory nitric oxide and nasal nitric oxide, 2005. Am J Respir Crit Care Med. 2005;171(8):912-30.

14. Saleh D, Ernst P, Lim S, Barnes PJ, Giaid A. Increased formation of the potent oxidant peroxynitrite in the airways of asthmatic patients is associated with induction of nitric oxide synthase: effect of inhaled glucocorticoid. FASEB J. 1998;12(11):929-37.

15. Stuehr DJ, Cho HJ, Kwon NS, Weise MF, Nathan CF. Purification and characterization of the cytokine-induced macrophage nitric oxide synthase: an FAD- and FMN-containing flavoprotein. Proc Natl Acad Sci U S A. 1991;88(17):7773-7.

16. Lyons CR, Orloff GJ, Cunningham JM. Molecular cloning and functional expression of an inducible nitric oxide synthase from a murine macrophage cell line. J Biol Chem. 1992;267(9):6370-4.

17. Xie QW, Cho HJ, Calaycay J, Mumford RA, Swiderek KM, Lee TD, Ding A, Troso T, Nathan C. Cloning and characterization of inducible nitric oxide synthase from mouse macrophages. Science. 1992;256(5054):225-8.

18. Nunokawa $Y$, Ishida $N$, Tanaka $S$. Cloning of inducible nitric oxide synthase in rat vascular smooth muscle cells. Biochem Biophys Res Commun. 1993;191(1):89-94.

19. Warner RL, Paine R 3rd, Christensen PJ, Marletta MA, Richards MK, Wilcoxen SE, Ward PA. Lung sources and cytokine requirements for in vivo expression of inducible nitric oxide synthase. Am J Respir Cell Mol Biol. 1995;12(6):649-61.

20. Yates $D H$. Role of exhaled nitric oxide in asthma. Immunol Cell Biol. 2001;79(2):178-90.

21. Bogdan C. Nitric oxide and the immune response. Nat Immunol. 2001;2(10):907-16.

22. Clancy RM, Abramson SB. Nitric oxide: a novel mediator of inflammation. Proc Soc Exp Biol Med. 1995;210(2):93-101.
23. Uetani K, Thomassen MJ, Erzurum SC. Nitric oxide synthase 2 through an autocrine loop via respiratory epithelial cell-derived mediator. Am J Physiol Lung Cell Mol Physiol. 2001;280(6):L1179-88.

24. Fujii Y, Magder S, Cernacek P, Goldberg P, Guo Y, Hussain $S N$. Endothelin receptor blockade attenuates lipopolysaccharide-induced pulmonary nitric oxide production. $\mathrm{Am} J$ Respir Crit Care Med. 2000;161(3 Pt 1):982-9.

25. Wang HH, Hsieh HL, Yang CM. Nitric oxide production by endothelin-1 enhances astrocytic migration via the tyrosine nitration of matrix metalloproteinase-9. J Cell Physiol. 2011;226(9):2244-56.

26. Alderton WK, Cooper CE, Knowles RG. Nitric oxide synthases: structure, function and inhibition. Biochem $J$. 2001;357(Pt 3):593-615.

27. Barnes PJ, Dweik RA, Gelb AF, Gibson PG, George SC, Grasemann H, Pavord ID, Ratjen F, Silkoff PE, Taylor DR, Zamel $N$. Exhaled nitric oxide in pulmonary diseases: a comprehensive review. Chest. 2010;138(3):682-92.

28. Gaston B, Drazen JM, Loscalzo J, Stamler JS. The biology of nitrogen oxides in the airways. Am J Respir Crit Care Med. 1994;149(2 Pt 1):538-51.

29. Pechkovsky DV, Zissel G, Goldmann T, Einhaus M, Taube C, Magnussen H, Schlaak M, Müller-Quernheim J. Pattern of NOS2 and NOS3 mRNA expression in human A549 cells and primary cultured AEC II. Am J Physiol Lung Cell Mol Physiol. 2002;282(4):L684-92.

30. Hollá LI, Bucková D, Kuhrová V, Stejskalová A, Francová $H$, Znojil V, Vácha J. Prevalence of endothelial nitric oxide synthase gene polymorphisms in patients with atopic asthma. Clin Exp Allergy. 2002;32(8):1193-8.

31. Maarsingh H, Leusink J, Bos IS, Zaagsma J, Meurs H. Arginase strongly impairs neuronal nitric oxide-mediated airway smooth muscle relaxation in allergic asthma. Respir Res. 2006;7:6.

32. Zuo L, Koozechian MS, Chen LL. Characterization of reactive nitrogen species in allergic asthma. Ann Allergy Asthma Immunol. 2014;112(1):18-22.

33. Hecker M, Cattaruzza M, Wagner AH. Regulation of inducible nitric oxide synthase gene expression in vascular smooth muscle cells. Gen Pharmacol. 1999;32(1):9-16.

34. Romanska HM, Polak JM, Coleman RA, James RS, Harmer $D W$, Allen JC, Bishop AE. iNOS gene upregulation is associated with the early proliferative response of human lung fibroblasts to cytokine stimulation. J Pathol. 2002;197(3):372-9.

35. Ermert M, Ruppert C, Günther A, Duncker HR, Seeger W, Ermert L. Cell-specific nitric oxide synthase-isoenzyme expression and regulation in response to endotoxin in intact rat lungs. Lab Invest. 2002;82(4):425-41.

36. Panaro MA, Brandonisio O, Acquafredda A, Sisto M, Mitolo $V$. Evidences for iNOS expression and nitric oxide production in the human macrophages. Curr Drug Targets Immune Endocr Metabol Disord. 2003;3(3):210-21. 
37. Prado CM, Leick-Maldonado EA, Yano L, Leme AS, Capelozzi VL, Martins MA, Tibério IF. Effects of nitric oxide synthases in chronic allergic airway inflammation and remodeling. Am J Respir Cell Mol Biol. 2006;35(4):457-65.

38. del Pozo V, de Arruda-Chaves E, de Andrés B, Cárdaba B, López-Farré A, Gallardo S, Cortegano I, Vidarte L, Jurado $A$, Sastre J, Palomino P, Lahoz C. Eosinophils transcribe and translate messenger RNA for inducible nitric oxide synthase. J Immunol. 1997;158(2):859-64.

39. Evans TJ, Buttery LD, Carpenter A, Springall DR, Polak JM, Cohen J. Cytokine-treated human neutrophils contain inducible nitric oxide synthase that produces nitration of ingested bacteria. Proc Natl Acad Sci U S A. 1996;93(18):9553-8.

40. Webb JL, Polak JM, Evans TJ. Effect of adhesion on inducible nitric oxide synthase (iNOS) production in purified human neutrophils. Clin Exp Immunol. 2001;123(1):42-8.

41. Lu L, Bonham CA, Chambers FG, Watkins SC, Hoffman RA, Simmons $R L$, Thomson $A W$. Induction of nitric oxide synthase in mouse dendritic cells by IFN-gamma, endotoxin, and interaction with allogeneic T cells: nitric oxide production is associated with dendritic cell apoptosis. J Immunol. 1996;157(8):3577-86.

42. McCauley $S D$, Gilchrist $M$, Befus $A D$. Nitric oxide: a major determinant of mast cell phenotype and function. Mem Inst Oswaldo Cruz. 2005;100 Suppl 1:11-4.

43. Gilchrist $M$, McCauley SD, Befus AD. Expression, localization, and regulation of NOS in human mast cell lines: effects on leukotriene production. Blood. 2004;104(2):462-9.

44. Bidri M, Ktorza S, Vouldoukis I, Le Goff L, Debré P, Guillosson JJ, Arock M. Nitric oxide pathway is induced by Fc epsilon RI and up-regulated by stem cell factor in mouse mast cells. Eur J Immunol. 1997;27(11):2907-13.

45. Inoue T, Suzuki Y, Yoshimaru T, Ra C. Nitric oxide protects mast cells from activation-induced cell death: the role of the phosphatidylinositol-3 kinase-Akt-endothelial nitric oxide synthase pathway. J Leukoc Biol. 2008;83(5):1218-29.

46. Gilchrist M, Savoie M, Nohara O, Wills FL, Wallace JL, Befus $A D$. Nitric oxide synthase and nitric oxide production in in vivo-derived mast cells. J Leukoc Biol. 2002;71(4):618-24.

47. Lin TJ, Hirji N, Nohara O, Stenton GR, Gilchrist M, Befus AD. Mast cells express novel CD8 molecules that selectively modulate mediator secretion. J Immunol. 1998;161(11):6265-72.

48. Suzuki Y, Inoue T, Ra $C$. Endothelial nitric oxide synthase is essential for nitric oxide generation, L-type Ca2+ channel activation and survival in RBL-2H3 mast cells. Biochim Biophys Acta. 2010;1803(3):372-85.

49. Furuke K, Burd PR, Horvath-Arcidiacono JA, Hori K, Mostowski H, Bloom ET. Human NK cells express endothelial nitric oxide synthase, and nitric oxide protects them from activation-induced cell death by regulating expression of TNF-alpha. J Immunol. 1999;163(3):1473-80.

50. Lancaster $J R J r$. Nitroxidative, nitrosative, and nitrative stress: kinetic predictions of reactive nitrogen species chem- istry under biological conditions. Chem Res Toxicol. 2006;19(9):1160-74.

51. Hess DT, Matsumoto A, Kim SO, Marshall HE, Stamler JS. Protein S-nitrosylation: purview and parameters. Nat Rev Mol Cell Biol. 2005;6(2):150-66.

52. Martinez MC, Andriantsitohaina R. Reactive nitrogen species: molecular mechanisms and potential significance in health and disease. Antioxid Redox Signal. 2009;11(3):669-702.

53. Alving $K$, Weitzberg E, Lundberg JM. Increased amount of nitric oxide in exhaled air of asthmatics. Eur Respir $J$. 1993;6(9):1368-70.

54. Kharitonov $S A$, Yates $D$, Robbins RA, Logan-Sinclair $R$, Shinebourne EA, Barnes PJ. Increased nitric oxide in exhaled air of asthmatic patients. Lancet. 1994;343(8890):133-5.

55. Massaro AF, Gaston B, Kita D, Fanta C, Stamler JS, Drazen $J M$. Expired nitric oxide levels during treatment of acute asthma. Am J Respir Crit Care Med. 1995;152(2):800-3.

56. Yates DH, Kharitonov SA, Robbins RA, Thomas PS, Barnes $P J$. Effect of a nitric oxide synthase inhibitor and a glucocorticosteroid on exhaled nitric oxide. Am J Respir Crit Care Med. 1995;152(3):892-6.

57. Hamid Q, Springall DR, Riveros-Moreno V, Chanez P, Howarth P, Redington A, Bousquet J, Godard P, Holgate S, Polak JM. Induction of nitric oxide synthase in asthma. Lancet. 1993;342(8886-8887):1510-3.

58. Guo FH, Comhair SA, Zheng S, Dweik RA, Eissa NT, Thomassen MJ, Calhoun W, Erzurum SC. Molecular mechanisms of increased nitric oxide (NO) in asthma: evidence for transcriptional and post-translational regulation of NO synthesis. J Immunol. 2000;164(11):5970-80.

59. De Sanctis GT, MacLean JA, Hamada K, Mehta S, Scott JA, Jiao A, Yandava CN, Kobzik L, Wolyniec WW, Fabian AJ, Venugopal CS, Grasemann H, Huang PL, Drazen JM. Contribution of nitric oxide synthases 1,2 , and 3 to airway hyperresponsiveness and inflammation in a murine model of asthma. J Exp Med. 1999;189(10):1621-30.

60. Feder LS, Stelts D, Chapman RW, Manfra D, Crawley $Y$, Jones H, Minnicozzi M, Fernandez X, Paster T, Egan RW, Kreutner W, Kung TT. Role of nitric oxide on eosinophilic lung inflammation in allergic mice. Am J Respir Cell Mol Biol. 1997;17(4):436-42.

61. Xiong Y, Karupiah G, Hogan SP, Foster PS, Ramsay AJ. Inhibition of allergic airway inflammation in mice lacking nitric oxide synthase 2. J Immunol. 1999;162(1):445-52.

62. Popov TA. Human exhaled breath analysis. Ann Allergy Asthma Immunol. 2011;106(6):451-6.

63. Jatakanon A, Lim S, Kharitonov SA, Chung KF, Barnes PJ. Correlation between exhaled nitric oxide, sputum eosinophils, and methacholine responsiveness in patients with mild asthma. Thorax. 1998;53(2):91-5.

64. Mattes J, Storm van's Gravesande $K$, Reining $U$, Alving $K$, Ihorst $G$, Henschen $M$, Kuehr J. NO in exhaled air is correlated with markers of eosinophilic airway inflammation in 
Nitrosative events in atopic asthma pathogenesis

corticosteroid-dependent childhood asthma. Eur Respir J. 1999;13(6):1391-5.

65. Piacentini GL, Bodini A, Costella S, Vicentini L, Mazzi P, Sperandio $S$, Boner $A L$. Exhaled nitric oxide and sputum eosinophil markers of inflammation in asthmatic children. Eur Respir J. 1999;13(6):1386-90.

66. Donohue JF, Jain N. Exhaled nitric oxide to predict corticosteroid responsiveness and reduce asthma exacerbation rates. Respir Med. 2013;107(7):943-52.

67. Haldar P, Brightling CE, Hargadon B, Gupta S, Monteiro W, Sousa A, Marshall RP, Bradding P, Green RH, Wardlaw $A J$, Pavord ID. Mepolizumab and exacerbations of refractory eosinophilic asthma. N Engl J Med. 2009;360(10):97384.

68. Corren J, Lemanske RF, Hanania NA, Korenblat PE, Parsey MV, Arron JR, Harris JM, Scheerens H, Wu LC, Su Z, Mosesova S, Eisner MD, Bohen SP, Matthews JG. Lebrikizumab treatment in adults with asthma. $N$ Engl $J$ Med. 2011;365(12):1088-98.

69. Warke TJ, Fitch PS, Brown V, Taylor R, Lyons JD, Ennis M, Shields $M D$. Exhaled nitric oxide correlates with airway eosinophils in childhood asthma. Thorax. 2002;57(5):383-7.

70. Bousquet J, Chanez P, Lacoste JY, Barnéon G, Ghavanian $N$, Enander I, Venge P, Ahlstedt S, Simony-Lafontaine J, Godard $P$, et al. Eosinophilic inflammation in asthma. $N$ Engl J Med. 1990;323(15):1033-9.

71. Meurs H, Maarsingh H, Zaagsma J. Arginase and asthma: novel insights into nitric oxide homeostasis and airway hyperresponsiveness. Trends Pharmacol Sci. 2003;24(9):450-5.

72. Yeadon $M$, Price $R$. Induction of calcium-independent nitric oxide synthase by allergen challenge in sensitized rat lung in vivo. Br J Pharmacol. 1995;116(6):2545-6.

73. Parilova $O O$, Shandrenko $S G$. Interconnection between nitric oxide formation and hypersensitivity parameters under guinea pig model of acute asthma with multiple challenges. Ukr Biochem J. 2015;87(5):113-23.

74. Trifilieff A, Fujitani Y, Mentz F, Dugas B, Fuentes M, Bertrand $C$. Inducible nitric oxide synthase inhibitors suppress airway inflammation in mice through down-regulation of chemokine expression. J Immunol. 2000;165(3):1526-33.

75. Pautz A, Art J, Hahn S, Nowag S, Voss C, Kleinert H. Regulation of the expression of inducible nitric oxide synthase. Nitric Oxide. 2010;23(2):75-93.

76. Alving K, Malinovschi A. Basic aspects of exhaled nitric oxide. European Respiratory Monograph. Plymouth, UK, Latimer Trend \& So Ltd, European Respiratory Society; 2010; 69:1-31.

77. Chibana K, Trudeau JB, Mustovich AT, Hu H, Zhao J, Balzar S, Chu HW, Wenzel SE. IL-13 induced increases in nitrite levels are primarily driven by increases in inducible nitric oxide synthase as compared with effects on arginases in human primary bronchial epithelial cells. Clin Exp Allergy. 2008;38(6):936-46.
78. Bove $P F$, van der Vliet $A$. Nitric oxide and reactive nitrogen species in airway epithelial signaling and inflammation. Free Radic Biol Med. 2006;41(4):515-27.

79. Mgbemena V, Segovia JA, Chang TH, Tsai SY, Cole GT, Hung CY, Bose $S$. Transactivation of inducible nitric oxide synthase gene by Kruppel-like factor 6 regulates apoptosis during influenza $\mathrm{A}$ virus infection. $J$ Immunol. 2012;189(2):606-15.

80. Ilmarinen-Salo P, Moilanen E, Kinnula VL, Kankaanranta $H$. Nitric oxide-induced eosinophil apoptosis is dependent on mitochondrial permeability transition ( $\mathrm{mPT}$ ), JNK and oxidative stress: apoptosis is preceded but not mediated by early mPT-dependent JNK activation. Respir Res. 2012;13:73.

81. Curran AD. The role of nitric oxide in the development of asthma. Int Arch Allergy Immunol. 1996;111(1):1-4.

82. Abbas AK, Murphy KM, Sher A. Functional diversity of helper T lymphocytes. Nature. 1996;383(6603):787-93.

83. Ouyang $W$, Ranganath $S H$, Weindel $K$, Bhattacharya $D$, Murphy TL, Sha WC, Murphy KM. Inhibition of Th1 development mediated by GATA-3 through an IL-4-independent mechanism. Immunity. 1998;9(5):745-55.

84. Ferber IA, Lee HJ, Zonin F, Heath V, Mui A, Arai N, O'Garra $A$. GATA-3 significantly downregulates IFN-gamma production from developing Th1 cells in addition to inducing IL-4 and IL-5 levels. Clin Immunol. 1999;91(2):134-44.

85. Chang RH, Feng $M H$, Liu WH, Lai MZ. Nitric oxide increased interleukin-4 expression in T lymphocytes. Immunology. 1997;90(3):364-9.

86. Niedbala W, Wei XQ, Campbell C, Thomson D, Komai-Koma $M$, Liew FY. Nitric oxide preferentially induces type $1 \mathrm{~T}$ cell differentiation by selectively up-regulating IL-12 receptor beta 2 expression via cGMP. Proc Natl Acad Sci U S A. 2002;99(25):16186-91.

87. Bauer H, Jung T, Tsikas D, Stichtenoth DO, Frölich JC, Neumann $C$. Nitric oxide inhibits the secretion of T-helper 1- and T-helper 2-associated cytokines in activated human $\mathrm{T}$ cells. Immunology. 1997;90(2):205-11.

88. Eriksson U, Egermann U, Bihl MP, Gambazzi F, Tamm M, Holt PG, Bingisser RM. Human bronchial epithelium controls $\mathrm{TH} 2$ responses by $\mathrm{TH} 1$-induced, nitric oxide-mediated STAT5 dephosphorylation: implications for the pathogenesis of asthma. J Immunol. 2005;175(4):2715-20.

89. Adler KB, Fischer BM, Li H, Chloe NH, Wright DT. Hyper secretion of cumin is response to inflammatory mediators by guinea pig tracheal epithelial cells in vitro is blocked by inhibition of nitric oxide synthesis. Am J Respir Cell Mol Biol. 1995;13:526-530.

90. Angeli P, Prado CM, Xisto DG, Silva PL, Pássaro CP, Nakazato HD, Leick-Maldonado EA, Martins MA, Rocco PR, Tibério IF. Effects of chronic L-NAME treatment lung tissue mechanics, eosinophilic and extracellular matrix responses induced by chronic pulmonary inflammation. Am J Physiol Lung Cell Mol Physiol. 2008;294(6):L1197-205. 
91. Prado CM, Leick-Maldonado EA, Kasahara DI, Capelozzi $V L$, Martins MA, Tibério IF. Effects of acute and chronic nitric oxide inhibition in an experimental model of chronic pulmonary allergic inflammation in guinea pigs. $\mathrm{Am} \mathrm{J}$ Physiol Lung Cell Mol Physiol. 2005;289(4):L677-83.

92. Iijima H, Duguet A, Eum SY, Hamid Q, Eidelman DH. Nitric oxide and protein nitration are eosinophil dependent in allergen-challenged mice. Am J Respir Crit Care Med. 2001;163(5):1233-40.

93. Starling CM, Prado CM, Leick-Maldonado EA, Lanças T, Reis FG, Aristóteles LR, Dolhnikoff M, Martins MA, Tibério $I F$. Inducible nitric oxide synthase inhibition attenuates lung tissue responsiveness and remodeling in a model of chronic pulmonary inflammation in guinea pigs. Respir Physiol Neurobiol. 2009;165(2-3):185-94.

94. Karpuzoglu E, Ahmed SA. Estrogen regulation of nitric oxide and inducible nitric oxide synthase (iNOS) in immune cells: implications for immunity, autoimmune diseases, and apoptosis. Nitric Oxide. 2006;15(3):177-86.

95. Thomassen MJ, Buhrow LT, Connors MJ, Kaneko FT, Erzurum SC, Kavuru MS. Nitric oxide inhibits inflammatory cytokine production by human alveolar macrophages. Am J Respir Cell Mol Biol. 1997;17(3):279-83.

96. Raychaudhuri B, Dweik R, Connors MJ, Buhrow L, Malur A, Drazba J, Arroliga AC, Erzurum SC, Kavuru MS, Thomassen $M J$. Nitric oxide blocks nuclear factor-kappaB activation in alveolar macrophages. Am J Respir Cell Mol Biol. 1999;21(3):311-6.

97. Sato E, Simpson KL, Grisham MB, Koyama S, Robbins RA. Reactive nitrogen and oxygen species attenuate interleukin8 -induced neutrophil chemotactic activity in vitro. $J$ Biol Chem. 2000;275(15):10826-30.

98. Kim YM, Talanian RV, Billiar TR. Nitric oxide inhibits apoptosis by preventing increases in caspase-3-like activity via two distinct mechanisms. $J$ Biol Chem. 1997;272(49):31138-48.

\section{Нітрозативні події в патогенезі атопічної астми \\ О. О. Парилова, Т. Т. Володіна, С. Г. Шандренко}

Кореляцію між високим рівнем оксиду азоту, що видихається та еозинофіл-опосередкованим запаленням дихальних шляхів у пацієнтів з атопічною бронхіальною астмою добре доведено. Це створює передумови існування регуляторного механізму зворотнього зв'язку між ними. Тому стаття стисло наводить свідчення стосовно біосинтезу, структурних особливостей ен- зиму, регуляції експресії його ізоформ та дії оксиду азоту, що допомагає з'ясувати молекулярні механізми завдяки яким оксид азоту сприяє загостренню перебігу захворювання. В попередній експериментальній роботі ми продемонстрували, що інфільтрат імунних клітин, які персистують в дихальних шляхах, робить внесок у синтез оксиду азоту в респіраторному тракті під час пізньої алергічної реакції за моделі гострої бронхіальної астми мурчаків з множинними провокаціями алергену. На основі цих даних автори констатують, що оксид азоту $є$ додатковим сигналом індукції відповіді Th2 ланки та залучений в складну мережу імунної регуляції, характерної для фенотипу атопічної астми.

Ключ ов і слов а: оксид азоту, атопічна астма, синтази оксиду азоту, алергічне запалення дихальних шляхів, еозинофілія.

\section{Нитрозативные события в патогенезе атопической астмы}

Е. А. Парилова, Т. Т. Володина, С. Г. Шандренко

Корреляция между высоким уровнем оксида азота в выдыхаемом воздухе и эозинофил-опосредованным воспалением дыхательных путей у пациентов с атопической бронхиальной астмой хорошо обоснована. Это порождает предпосылку, что существует механизм регулирования обратной связи между ними. Таким образом, статья кратко описывает данные касающиеся биосинтеза, структурных особенностей энзима, регулирования экспрессии его изоформ и воздействия оксида азота, которые помогают выяснить молекулярные механизмы, благодаря чему оксид азота селективно содействует обострению астмы. В предыдущей экспериментальной работе мы показали, что инфильтрат иммунных клеток в дыхательных путях дополняет синтез оксида азота в респираторном тракте во время аллергического воспаления на модели острой бронхиальной астмы морских свинок с множественными провокациями аллергена. На основании этих данных авторы констатируют, что оксид азота представляет собой дополнительный сигнал индукции ответа Th2 звена и значительно вовлечен в сложную сеть иммунной регуляции, отличительной для фенотипа атопической астмы.

К л юч е в ы е с л о в а: оксид азота, атопическая астма, синтазы оксида азота, аллергическое воспаление дыхательных путей, эозинофилия.

Received 29.09.2015 